\title{
Pengaruh Tingkat Bagi Hasil, Financing to Deposit Ratio (FDR) Dan Tingkat Inflasi Terhadap Deposito Mudharabah Pada Bank Umum Syariah (BUS) Periode $2014-2017$
}

\author{
Firda Izzati Febriani \\ Program Studi Ekonomi Syariah, Fakultas Agama Islam \\ Universitas Muhammadiyah Malang \\ Email: firdaizzati5@gmail.com
}

\begin{abstract}
This study aims to determine the factors affect the amount of mudharaba deposits in Sharia Commercial Banks period 2014-2017. Factors affecting mudharaba deposits are used in this study which profit sharing rate, liquidity level measured by financing to deposit ratio, and inflation rate. The method used in this research is quantitative descriptive. The data used are secondary time series for the period of January 2014-December 2017 which has been published by the website of Bank Indonesia and Otoritas Jasa Keuangan (OJK). The method of analysis used is multiple linear regression. The results of this study indicate that the profit sharing rate, financing to deposit ratio and inflation rate significantly influence the number of mudharaba deposit accumulation. Variable of profit sharing rate have a positive relation to mudharaba deposit. However, the variable of financing to deposit ratio and inflation rate have a negative relation to mudharaba deposit.
\end{abstract}

Keywords: Mudharaba, Profit Sharing, Financing to Deposit Ratio, inflation. 


\begin{abstract}
ABSTRAK
Penelitian ini bertujuan untuk mengetahui faktor-faktor yang mempengaruhi jumlah deposito mudharabah pada Bank Umum Syariah periode 2014-2017. Faktor-faktor yang mempengaruhi deposito mudharabah yang digunakan dalam penelitian ini adalah tingkat bagi hasil, tingkat likuiditas yang diukur dengan financing to deposit ratio dan inflasi. Pendekatan yang digunakan dalam penelitian ini adalah deskriptif kuantitatif. Data yang digunakan adalah data sekunder berupa data time series periode Januari 2014-Desember 2017 yang telah diterbitkan oleh website Bank Indonesia dan Otoritas Jasa Keuangan. Metode analisis yang digunakan adalah regresi linier berganda. Hasil penelitian ini menunjukkan bahwa tingkat bagi hasil, financing to deposit ratio dan tingkat inflasi berpengaruh signifikan terhadap jumlah penghimpunan deposito mudharabah. Variabel tingkat bagi hasil menunjukkan hubungan positif terhadap jumlah penghimpunan dana deposito mudharabah. Namun, variabel financing to deposit ratio dan tingkat inflasi mempunyai hubungan yang negatif atau lawan arah terhadap jumlah deposito mudharabah.
\end{abstract}

Kata Kunci: Mudharabah, Bagi Hasil, Financing to Deposit Ratio, Inflasi.

\title{
1. Pendahuluan
}

Keuangan syariah di Indonesia telah berkembang lebih dari dua dekade sejak beroperasinya Bank Muamalat Indonesia, sebagai bank syariah pertama di Indonesia. Namun demikian, pertumbuhan keuangan syariah belum dapat mengimbangi pertumbuhan keuangan konvensional. Namun apabila dilihat dari setiap jenis produk syariah, hingga akhir Desember 2016, terdapat beberapa produk syariah yang market share-nya di atas $5 \%$. Perbankan syariah dinilai perlu menjaga momentum pertumbuhan dan pangsa pasar yang berlangsung sepanjang 2017 (http://www.ojk.go.id). Hingga Desember 2017, jumlah bank syariah di Indonesia berjumlah 201 bank syariah yang terdiri dari 13 Bank Umum Syariah (BUS), 21 Unit Usaha Syariah (UUS), dan 167 Bank Pembiayaan Rakyat Syariah (BPRS). Peningkatan jaringan kantor bank syariah setiap tahunnya telah mendorong meningkatnya volume usaha bank syariah yang tercermin dalam peningkatan aset, dana pihak ketiga (DPK) dan pembiayaan.

Pada sebagian besar atau setiap bank, dana masyarakat yang bisa dikatakan sebagai dana pihak ketiga ini umumnya merupakan dana terbesar yang dimiliki. Hal ini sesuai dengan fungsi bank sebagai penghimpun dana dari masyarakat. Sampai tahun 2017, proporsi terbesar dalam penghimpunan dana pihak ketiga berasal dari produk perbankan syariah yakni deposito mudharabah pada bank 
syariah sebesar 196,266 milyar rupiah dari total DPK yang berjumlah 334,719 milyar rupiah. Hal ini menandakan bahwa deposito mudharabah mengambil $58,63 \%$ proporsi dari total dana pihak ketiga (www.ojk.go.id).

Deposito mudharabah menjadi produk yang diminati nasabah dibandingkan dengan produk lainnya karena dianggap lebih menguntungkan nasabah. Hal ini dikarenakan preferensi masyarakat yang masih cenderung memilih produk yang memberikan imbal hasil yang tinggi. Penelitian ini memfokuskan pada faktorfaktor yang mempengaruhi deposito mudharabah. Alasan fokus penelitian ini pada deposito mudharabah ialah karena deposito mudharabah mengalami perkembangan yang signifikan dari tahun ke tahun sampai dengan tahun 2017 yakni sebesar 62,4\% dihitung dari tahun 2014. Pada tahun 2014, jumlah deposito mudharabah berjangka sebesar 85.707 milyar rupiah meningkat tajam hingga tahun 2017,yakni sebesar 137.377 milyar rupiah (www.ojk.go.id).

Penelitian ini ingin menguji variabel tingkat bagi hasil Deposito Mudharabah, tingkat likuiditas yang diukur dari FDR, serta tingkat inflasi pada Bank Umum Syariah Periode 2014-2017.

\section{Tinjauan Pustaka}

Financing to deposit ratio menyatakan kemampuan bank dalam membayar kembali penarikan dana yang dilakukan deposan dengan mengandalkan pembiayaan yang diberikan sebagai sumber likuiditasnya, atau dengan kata lain seberapa jauh pemberian pembiayaan kepada nasabah dapat mengimbangi kewajiban bank untuk segera memenuhi permintaan deposan yang hendak menarik kembali dananya yang telah disalurkan oleh bank berupa pembiayaan.Semakin tinggi rasio tersebut memberikan indikasi rendahnya kemampuan likuiditas bank yang bersangkutan (Suwiknyo,2010: 148).

$$
\text { Rumus: FDR } \frac{\text { Total Pembiayaan yang diberikan }}{\text { Total Dana Pihak ke III+Modal Inti }}=\mathrm{x} 100 \%
$$

Menurut Andriyanti dan Wasilah (2010), tingginya FDR bank syariah dapat diartikan bahwa likuiditas bank tersebut rendah. Hal ini disebabkan semakin tinggi FDR bank, maka resiko bank terhadap pembiayaan bermasalah juga akan naik. Sehingga bank syariah akan rawan terhadap krisis ketika terjadi penarikan simpanan dari deposan secara serentak dan dalam jumlah besar. Kebangkrutan bank dapat dipicu oleh ketidakmampuan bank dalam memenuhi kebutuhan likuiditasnya. Masyarakat hanya menginginkan lembaga keuangan yang dapat dipercaya dalam mengembangkan dana yang dimilikinya, khususnya pada perbankan (an-Nabahan, 2000: 117). Jadi meskipun manajer bank berusaha untuk menghasilkan keuntungan setinggi-tingginya, secara simultan mereka harus juga memperhatikan adanya kemungkinan risiko yang timbul menyertai keputusan manajemen tentang struktur aset dan liabilitasnya (Muhammad, 2002: 309). 
Terkait dengan tingkat inflasi dan pengaruhnya terhadap deposito mudharabah. Cahyono (2009) dalam penelitiannya menyebutkan bahwa inflasi adalah suatu proses meningkatnya harga-harga secara umum dan terus menerus berkaitan dengan mekanisme pasar yang dapat disebabkan oleh berbagai faktor diantaranya konsumsi masyarakat yang meningkat atau adanya ketidak lancaran distribusi barang. Kenaikan tingkat inflasi akan berimbas kepada peningkatan jumlah konsumsi dikarenakan adanya kenaikan harga-harga umum secara terus-menerus yang pada akhirnya akan mengurangi bagian dalam tabungan (Novianto \& Hadiwidjojo, 2013). Seperti yang diungkapkan Keyness, pada saat $\mathrm{Y}=\mathrm{C}$ maka tidak ada tabungan $(S=0)$ sebab semua pendapatan habis untuk konsumsi. Begitu pula dengan deposito yang dilakukan deposan juga dipengaruhi kondisi makro ini (Nopirin, 2015: 65). Berdasarkan teori diatas, inflasi akan mempengaruhi jumlah tabungan. Apabila tingkat inflasi semakin besar, maka akan berpengaruh negatif terhadap tabungan yang mengakibatkan jumlah deposito mudharabah akan menurun. Hal ini sesuai dengan penelitian Novianto dan Hadiwidjdjo yang menyatakan bahwa inflasi berpengaruh negatif terhadap deposito mudharabah (Novianto \& Hadiwidjojo, 2013).

\subsection{Bank Syariah}

Bank syariah adalah bank yang beroperasi dengan tidak mengandalkan pada bunga. Bank Islam atau biasa disebut dengan bank tanpa bunga adalah lembaga keuangan atau perbankan yang operasional dan produknya dikembangkan berlandaskan pada Al Qur'an dan Hadis Nabi. Atau dengan kata lain, bank Islam adalah lembaga keuangan yang lembaga pokoknya memberikan pembiayaan dan jasa-jasa lainnya dalam lalu lintas pembayaran serta peredaran uang yang pengoperasiannya disesuaikan dengan prinsip syariat Islam. Bank Islam lahir di Indonesia, yang gencarnya pada tahun 90-an atau tepatnya setelah Undangundang No. 7 Tahun 1992, yang direvisi dengan Undang-Undang Perbankan No.10 Tahun 1998, dalam bentuk sebuah bank yang beroperasinya dengan sistem bagi hasil atau bank syariah. Keberadaan bank syariah semakin mapan setelah diundangkannya UU No. 21 Tahun 2010 tentang Perbankan Syariah (Muhammad, 2015: 2-3).

Lembaga keuangan atau perbankan yang memberi pembiayaan dan jasa-jasa lainnya dalam lalu lintas pembayaran dan peredaran uang serta pengoperasiannya didasarkan pada prinsip-prinsip syariah yakni mengacu pada ketentuan Al-Quran dan Al-Hadits dan juga aktivitas meninggalkan riba dan tidak mengandalkan bunga (Laksmana, 2009: 10). Dalam konteks corporate governance, perbedaan antara Bank syariah dan bank konvensional adalah keberadaan Dewan Pengawas Syariah (DPS) yang bersifat independen dan kedudukannya sejajar dengan Dewan Komisaris. Tugas utama DPS adalah melakukan pengawasan pada bank syariah yang mengacu fatwa Dewan Syariah Nasional (DSN) serta norma-norma syariah menyangkut operasionalisasi bank, produk bank islam dan moral manajemen. 


\subsection{Deposito Mudharabah}

Deposito berjangka atau time deposit adalah simpanan yang penarikannya hanya dapat dilakukan pada waktu tertentu menurut perjanjian antara penyimpan dengan bank yang bersangkutan. Jangka waktu jatuh tempo deposito ini pada umumnya adalah: 1 bulan, 3 bulan, 6 bulan, 12 bulan dan 24 bulan (Daiamat,1993: 102). Secara singkat mudharabah atau penanaman modal adalah penyerahan modal uang kepada orang yang berniaga sehingga ia mendapatkan presentase keuntungan. Sebagai suatu bentuk kontrak, mudharabah merupakan akad bagi hasil ketika pemilik dana/modal (pemodal), biasa disebut shahibul maal, menyediakan modal 100\% kepada pengusaha sebagai pengelola, biasa disebut mudharib, untuk melakukan aktivitas produktif dengan syarat bahwa keuntungan yang dihasilkan akan dibagi diantara mereka menurut kesepakatan yang ditentukan sebelumnya dalam akad (Ascarya, 2011: 61).

Menabung atau mendepositokan uang di bank adalah tindakan yang dianjurkan dalam Islam, karena dengan menabung berarti seorang muslim mempersiapkan diri untuk pelaksanaan masa yang akan datang sekaligus untuk menghadapi hal-hal yang tidak diinginkan (QS. al-Hasyr[59]: 18). Bagi hasil adalah bentuk (perolehan aktivitas usaha) dari kontrak investasi dari waktu ke waktu,tidak pasti dan tidak tetap pada bank Islam. Besar kecilnya perolehan kembali itu tergantung pada hasil usaha yang benar-benar diperoleh bank Islam.Dalam sistem perbankan islam bagi hasil merupakan suatu mekanisme yang dilakukan oleh bank islam (mudharib) dalam upaya memperoleh hasil dan membagikannya kembali kepada para pemilik dana (shahibul maal) sesuai kontrak yang disepakati bersama pada awal kontrak (akad) antara nasabah dengan Bank Islam (Rivai, 2010: 80). Oleh karena itu dapat disimpulkan rumus perhitungan bagi hasil deposito mudharabah apabila persentase tingkat bagi hasil belum diketahui adalah:

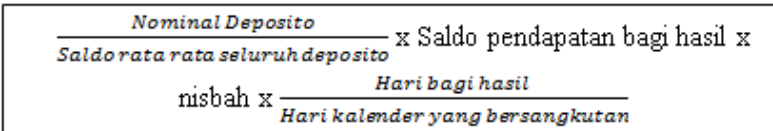

Pada dasarnya bila dikaitkan dengan perilaku konsumen, teori klasik tentang tingkat bunga dapat mewakili teori yang menjelaskan pengaruh bagi hasil pada bank syariah. Teori klasik tentang tingkat bunga sendiri menjelaskan, bahwa tabungan merupakan fungsi dari tingkat bunga, artinya semakin besar tingkat bunga maka akan semakin mendorong keinginan masyarakat untuk menabung. Hal ini bisa dikaitkan karena tingkat suku bunga dan bagi hasil sama-sama merupakan imbal jasa yang diberikan oleh bank kepada deposan atas dana yang disimpan di bank (Natalia, 2014: 4).

Jika dikaitkan dengan perilaku konsumen, masyarakat yang didasari profit oriented, akan melihat tingkat bagi hasil yang ditawarkan oleh bank syariah. Apabila tingkat bagi hasil meningkat, maka akan berpengaruh positif terhadap 
jumlah simpanan deposito mudharabah. Seperti yang diungkapkan Haron dan Ahmad (2000) dalam penelitiannya.

\section{Metode Penelitian}

Penelitian ini menggunakan penelitian deskriptif kuantitatif. Populasi dalam penelitian ini adalah Bank Umum Syariah yang ada di Indonesia yang mencakup 13 bank syariah. Penelitian ini menggunakan teknik sensus, yaitu cara pengumpulan data dimana seluruh elemen populasi diselidiki satu persatu. Data yang diperoleh sebagai hasil pengolahan sensus disebut data yang sebenarnya atau parameter (Supranto, 2000: 21). Jenis data yang digunakan adalah data sekunder. Metode pengumpulan data menggunakan teknik dokumentasi. Data yang digunakan dalam penelitian ini mencakup keseluruhan data bank umum syariah di Indonesia yang telah diterbitkan BI dan OJK dari tahun 2014 hingga 2017. Pemilihan tahun 2014 hingga 2017 sendiri didasarkan pada waktu relatif yang terbaru pada saat penelitian ini dilakukan. Dalam penelitian ini akan digunakan model regresi linier berganda karena memiliki variabel penduga lebih dari satu yaitu $X_{1}$ sampai Xn (Supranto, 2000: 21). Adapun model regresi yang digunakan adalah sebagai berikut:

$$
\mathrm{Y}=\alpha+\mathrm{b}_{1} \mathrm{x}_{1}+\mathrm{b}_{2} \mathrm{x}_{2}+\mathrm{b}_{3} \mathrm{x}_{3}+e
$$

Adapun sampel dari penelitian ini adalah sejumlah Bank Umum Syariah (BUS) sebagai berikut:

Tabel 1.1

Bank Umum Syariah di Indonesia

\begin{tabular}{cc}
\hline No & Nama Bank Umum Syariah \\
\hline 1 & Bank Muamalat Indonesia \\
\hline 2 & Bank Syariah Mandiri \\
\hline 3 & Bank Mega Syariah Indonesia \\
\hline 4 & BCA Syariah \\
\hline 5 & BNI Syariah \\
\hline 6 & BRI Syariah \\
\hline 7 & Bank Victoria Syariah \\
\hline 8 & Bank Syariah Bukopin \\
\hline 9 & Bank Panin Dubai Syariah \\
\hline 10 & Bank Aceh Syariah \\
\hline 11 & Maybank Syariah \\
\hline 12 & BJB Syariah
\end{tabular}




\section{Pembahasan}

\subsection{Pengaruh Komposisi Dewan Komisaris terhadap Profitabilitas BUS}

Berdasarkan hasil pengujian data, diketahui bahwa variabel tingkat bagi hasil (TBH) mempunyai koefisien sebesar 0,012 yang artinya jika tingkat bagi hasil yang diharapkan nasabah naik sebesar $1 \%$,maka jumlah deposito mudharabah Bank Umum Syariah akan naik sebesar 0,012 milyar rupiah dengan asumsi ceteris paribus. Sementara Variabel Financing to deposit ratio (FDR) mempunyai koefisien sebesar -0,009 yang berarti jika FDR naik sebesar 1\%, maka jumlah deposito mudharabah pada Bank Umum Syariah akan turun sebesar 0,009 milyar rupiah dengan asumsi ceteris paribus. Di sisi lain, Variabel Inflasi (INFL) mempunyai koefisien sebesar -0,020 artinya jika inflasi naik sebesar $1 \%$, maka jumlah deposito mudharabah pada Bank Umum Syariah akan turun sebesar 0,020 milyar rupiah dengan asumsi ceteris paribus.

Tabel 1.2

Nilai Hasil Analisis Regresi Berganda

\begin{tabular}{|c|c|c|c|c|}
\hline \multicolumn{2}{|c|}{ Variabel } & \multirow{2}{*}{$\begin{array}{c}\text { Koef. Regresi } \\
\text { B }\end{array}$} & \multirow[b]{2}{*}{$\operatorname{Sig} \mathbf{t}$} & \multirow[b]{2}{*}{ Standar error } \\
\hline Terikat & Bebas & & & \\
\hline \multirow{3}{*}{$\begin{array}{c}\text { Jumlah } \\
\text { Deposito } \\
\text { Mudharabah } \\
\text { (Y) }\end{array}$} & $\mathrm{TBH}\left(\mathrm{X}_{1}\right)$ & 0,012 & 0,005 & 0,004 \\
\hline & FDR $\left(X_{2}\right)$ & $-0,009$ & 0,000 & 0,001 \\
\hline & Inflasi $\left(\mathrm{X}_{3}\right)$ & $-0,020$ & 0,000 & 0,004 \\
\hline Konstanta & & 5,905 & & \\
\hline $\mathrm{R}$ & & 0,985 & & \\
\hline$R$ square & & 0,970 & & \\
\hline Adjusted $R$ square & & 0,968 & & \\
\hline Signifikasi F & & 0,000 & & \\
\hline N (Sampel) & & 48 & & \\
\hline
\end{tabular}

Dalam konteks Koefisien Determinasi $\left(R^{2}\right)$, sebagaimana table 1.1. di atas, diketahui Nilai $\left(R^{2}\right)$ besarnya antara $0<\left(R^{2}\right)<1$, dimana semakin mendekati 1 maka dapat dinyatakan model semakin baik. Hasil estimasi memiliki nilai $\mathrm{R}$ square sebesar 0,970 atau 97\%. Hal ini berarti kemampuan variabel bebas yang terdiri dari tingkat bagi hasil, FDR dan inflasi dalam menjelaskan variabel terikat yaitu Jumlah Deposito Mudharabah sebesar 0.970 (97\%), sedangkan sisanya $3 \%$ $(1-0.970=0.03)$ dijelaskan oleh variabel lain di luar model yang secara implisit tercermin pada variabel pengganggu. 
Sementara itu, berdasarkan uji anova di table 1.2. berikut, pengujian hipotesis dengan menggunakan uji $\mathrm{F}$ nilai $\mathrm{F}$ hitung diperoleh sebesar 470.638 dengan signifikansi sebesar 0.000 , Lalu $\mathrm{F}$ tabel dengan menggunakan tingkat keyakinan sebesar $95 \%(\alpha=0,05)$, df 1 (jumlah variabel-1) atau (3-1=2) dan df2 (n-k-1) atau $(48-3-1)=44$ ( $\mathrm{n}$ adalah jumlah data dan $\mathrm{k}$ adalah variabel independen). Maka hasil yang didapatkan oleh $F$ tabel (2;44) adalah 3,21. Maka dapat diketahui bahwa $F$ hitung > F tabel yaitu sebesar 3,21 sehingga > F tabel $(470,638>3,21)$ dan nilai signifikasi $0,000<0,05$ maka hipotesis diterima yang menyatakan bahwa variabel bebas secara simultan (bersama-sama berpengaruh terhadap jumlah penghimpunan deposito mudharabah,

Tabel 1.2

Hasil Uji F

\begin{tabular}{|l|l|l|l|}
\hline F hitung & Sig. & F tabel & Keterangan \\
\hline 470,638 & 0,000 & 3,21 & $\begin{array}{c}\text { Berpengaruh } \\
\text { secara simultan }\end{array}$ \\
\hline
\end{tabular}

Berdasarkan hasil pengujian secara parsial, variabel Tingkat Bagi Hasil menunjukkan hasil berpengaruh signifikan terhadap Jumlah Penghimpunan Dana Pihak ketiga deposito mudharabah yang ditunjukkan dengan nilai $t_{\text {hitung }}$ sebesar 2.969 dengan tingkat signifikansi sebesar 0,005 serta $t_{\text {tabel }}$ sebesar 2.014. Variabel FDR menunjukkan hasil berpengaruh signifikan tetapi memiliki hubungan yang negatif terhadap Jumlah Penghimpunan Dana Pihak ketiga deposito mudharabah yang ditunjukkan dengan nilai thitung sebesar 11.210 dengan tingkat signifikansi sebesar 0,000 serta tabel sebesar 2.014.

Inflasi menunjukkan hasil berpengaruh signifikan akan tetapi memiliki hubungan negatif terhadap Jumlah Penghimpunan Dana Pihak ketiga deposito mudharabah yang ditunjukkan dengan nilai $t_{\text {hitung }}$ sebesar 5.387 dengan tingkat signifikansi sebesar 0,000 serta $t_{\text {tabel }}$ sebesar 2.014.

\section{Tabel 1.3}

Uji T

\begin{tabular}{|l|l|l|l|l|}
\hline Variabel & t hitung & Sig. & t tabel & Keterangan \\
\hline $\mathrm{TBH}\left(\mathrm{X}_{1}\right)$ & 2,969 & 0,005 & 2,014 & Signifikan \\
\hline FDR $\left(\mathrm{X}_{2}\right)$ & $-(-11,210)$ & 0,000 & 2,014 & Signifikan \\
\hline Inflasi $\left(\mathrm{X}_{4}\right)$ & $-(-5,387)$ & 0,000 & 2,014 & Signifikan \\
\hline
\end{tabular}




\subsection{Pengaruh Tingkat Bagi Hasil terhadap Deposito Mudharabah}

Hasil pengujian terhadap tingkat bagi hasil menunjukkan bahwa tingkat bagi hasil memiliki pengaruh positif terhadap deposito mudharabah. Temuan ini mendukung penelitian Haron dan Ahmad (2000) yang menjelaskan setiap kenaikan pada tingkat keuntungan yang diberikan oleh bank Islam maka akan meningkatkan jumlah tabungan. Fakta ini menunjukkan bahwa masyarakat dalam menyimpan dananya dibank masih dipengaruhi oleh motif mencari keuntungan. Hasil ini sejalan dengan penelitian penelitian Diyanto dan Savitri (2015), sehingga semakin besarnya tingkat bagi hasil, semakin besar pula dana pihak ketiga yang disimpan di Bank Syariah. Namun juga mengartikan bahwa masyarakat sudah mulai mengerti akan pentingnya syariah Islam yang mengharamkan riba sebagaimana dalam al-Qur'an (QS. al-Baqarah[2]: 278). Ayat tersebut menggambarkan bagaimana Allah memerintahkan kepada seluruh orang yang beriman untuk meninggalkan sisa riba dari setiap piutang. Jika benar-benar masih melakukan riba maka Allah dan Rasul-Nya akan memerangi mereka. Konsep anti riba dalam Al-Qur'an melalui tahapan pertama,menggambarkan adanya unsur negatif didalamnya. Kedua,berisi isyarat tentang keharamannya. Ketiga, dinyatakan secara eksplisit keharaman dari salah satu bentuknya. Tahap keempat, diharamkan secara total dalam berbagai bentuknya. Dengan demikian, keharaman riba dalam Al-Qur'an sudah secara tegas dijelaskan dalam ayat diatas.

\subsection{Pengaruh FDR terhadap Deposito Mudharabah}

Rasio FDR mempunyai pengaruh negatif yang signifikan terhadap Deposito Mudharabah. Hal ini mendukung penelitian Andriyanti dan Wasilah (2010) yang menunjukkan bahwa tingkat likuiditas memiliki kecenderungan negatif terhadap deposito mudharabah. Semakin tinggi rasio FDR menandakan bahwa semakin rendah kemampuan likuiditas bank tersebut,karena FDR yang terlampau tinggi menunjukkan jumlah DPK yang tidak mampu menutupi pembiayaan yang disalurkan. Sehingga nasabah akan memperhitungkan kembali untuk menyimpan dananya di bank tersebut dan cenderung untuk menarik dananya, karena nasabah akan menghindari risiko likuiditas yang mungkin akan dihadapi oleh bank.

Pemicu utama kebangkrutan yang dialami oleh bank baik yang besar maupun yang kecil, bukanlah karena kerugian yang dideritanya, melainkan lebih kepada ketidakmampuan bank untuk memenuhi likuiditasnya. Likuiditas yang tersedia harus cukup, tidak boleh terlalu kecil sehingga mengganggu kebutuhan operasional sehari-hari,tetapi tidak boleh terlalu besar karena akan menurunkan efisiensi dan berdampak pada rendahnya tingkat profitabilitas (Muhammad, 2002: 311). Maka dari itu dapat disimpulkan karena kekhawatiran masyarakat akan risiko likuiditas, apabila rasio FDR semakin tinggi, maka jumlah deposito mudharabah akan turun. 


\subsection{Pengaruh Tingkat Inflasi terhadap Deposito Mudharabah}

Hasil pengujian pada variabel inflasi menunjukkan bahwa inflasi berpengaruh negatif signifikan terhadap jumlah deposito mudharabah. Sesuai dengan penelitian Novianto dan Hadiwidjojo (2013) yang menyatakan bahwa tingkat inflasi mempengaruhi dana pihak ketiga perbankan syariah. Apabila tingkat inflasi naik, maka jumlah DPK perbankan syariah akan mengalami penurunan. Hal ini diakibatkan penarikan dana oleh nasabah untuk kebutuhan konsumsi. Inflasi mengakibatkan penurunan daya beli mata uang sehingga dibutuhkan uang dalam jumlah lebih banyak untuk mengkonsumsi barang yang sama, dikarenakan harga-harga naik. Tingkat inflasi dalam skala ringan ataupun berat juga sangat mempengaruhi minat masyarakat untuk menyimpan dananya di bank, semakin berat skala inflasinya maka masyarakat cenderung tidak berminat untuk menabung karena dana yang dimilikinya lebih banyak digunakan untuk konsumsi daripada saving.

\section{Kesimpulan}

Berdasarkan uraian hasil penelitian diatas, maka dapat disimpulkan sebagai berikut. Pertama, faktor yang mempengaruhi jumlah deposito mudharabah pada Bank Umum Syariah periode tahun 2014 - 2017 di penelitian ini adalah tingkat bagi hasil, financing to deposit ratio dan tingkat inflasi. Variabel tingkat bagi hasil berpengaruh positif signifikan terhadap jumlah deposito mudharabah pada Bank Umum Syariah. Hal ini dapat dilihat dari nilai signifikasi sebesar 0,005 yang berarti lebih kecil dari derajat kesalahan sebesar 0,05 dan mempunyai nilai koefisien regresi sebesar 0,012 .

Variabel FDR berpengaruh negatif terhadap jumlah deposito mudharabah pada Bank Umum Syariah, hal ini bisa dilihat dari koefisien regresi sebesar -0,009 . Nilai signifikasi sebesar 0,000 lebih kecil dari pada derajat kesalahan yaitu 0,05 yang mengartikan bahwa variabel tersebut berpengaruh secara signifikan.Tingkat inflasi juga berpengaruh negatif terhadap jumlah deposito mudharabah pada Bank Umum Syariah, hal ini bisa dilihat dari koefisien regresi sebesar -0,020 . Nilai signifikasi sebesar 0,000 lebih kecil dari pada derajat kesalahan yaitu 0,05 yang mengartikan bahwa variabel tersebut berpengaruh secara signifikan.Untuk penelitian selanjutnya, bisa ditambahkan variabel yang diduga mempengaruhi deposito mudharabah pada Bank Umum Syariah baik dari faktor internal maupun eksternalnya. Penambahan variabel seperti variabel PDB yang terdapat dalam penelitian Abdullah Syakur Novianto (2013) bisa dipertimbangkan. Penambahan tahun penelitian pun dibutuhkan, untuk mendapat hasil yang lebih baik lagi di masa yang akan datang. 


\section{Daftar Pustaka}

Ascarya. 2011. Akad dan Produk Bank Syariah. (Jakarta: PT Raja Grafindo Persada)

Andriyanti, Ani dan Wasilah, 2010. "Faktor-Faktor yang Mempengaruhi Dana Pihak Ketiga (Deposito Mudharabah 1 Bulan) pada Bank Muamalat Indonesia", Simposium Nasional Akutansi XIII Purwokerto.

Cahyono, Ari. 2009. "Pengaruh Indikator Makroekonomi Terhadap Dana Pihak Ketiga dan Pembiayaan Bank Syariah Mandiri” (Tesis Magister Sains Universitas Indonesia, Jakarta)

Edwin, Mustafa. 2006. Pengenalan Ekslusif Ekonomi Islam.

an-Nabahan, Faruq M. 2000. Sistem Ekonomi Islam: Pilihan Setelah Kegagalan Sistem Kapitalis dan Sosialis, terj. Muhadi Zainuddin, (Yogyakarta: UII Press)

Haron, Sudin and Norafifah Ahmad. The Effects Of Conventional Interest Rates And Rate of Profit On Funds Deposited With Islamic Banking System In Malaysia. International Journal of Islamic Financial Services Vol. 1 No.4

Muhammad. 2002. Manajemen Bank Syariah.(Yogyakarta: UPP AMPYKPN) 2015. Manajemen Dana Bank Syariah.(Jakarta: Rajawali Press)

Natalia, Evi dkk. 2014.Pengaruh Tingkat Bagi Hasil Deposito Bank Syariah dan Suku Bunga Deposito Bank Umum Terhadap Jumlah Simpanan Deposito Mudharabah (Bank Syariah Mandiri Periode 2009-2010), Jurnal Administrasi Bisnis Vol.9 No.1.

Nopirin.2015. Ekonomi Moneter.(Yogyakarta: BPFE)

Rivai,Veithzal. 2010. Islamic Banking: Sebuah teori,konsep,dan aplikasi. (Jakarta: Bumi Aksara)

Siamat, Dahlan. 1993. Manajemen Bank Umum.(Jakarta: Intermedia)

Supranto, J. 2002. Statistik Teori dan Aplikasi. (Jakarta: Erlangga)

Suwiknyo, Dwi. 2010. Kompilasi Tafsir Ayat-Ayat Ekonomi Islam. (Yogyakarta: Pustaka Pelajar)

2010. Analisis Laporan Keuangan Perbankan Syariah. (Yogyakarta: Pustaka Pelajar)

Syakur Novianto, Abdullah dan Djumilah Hadiwidjojo.2013. "Analisis Faktor Faktor yang Mempengaruhi Penghimpunan Deposito Mudharabah Perbankan Syariah di Indonesia”. Jurnal Aplikasi Manajemen Vol 11 No.4.

http://www.ojk.go.id,diakses tanggal 20 maret 2018 